\title{
Ladder, tree, web: The ages of biological understanding
}

\author{
Kalevi Kull \\ Dept. of Semiotics, Tartu University \\ Tiigi 78, 50410 Tartu, Estonia \\ e-mail: kalevi@zbi.ee
}

\begin{abstract}
Fundamental turns in biological understanding can be interpreted as replacements of deep models that organise the biological knowledge. Three deep models distinguished here are a holistic ladder model that sees all levels of nature being complete (from Aristotle to the 18th century), a modernist tree model that emphasises progress and evolution (from Enlightenment to the recent times), and a web model that evaluates diversity (since the 20th century). The turn from the tree model to the web model in biology includes (1) a transfer from modern to postmodern approaches, (2) a shift of semiotic threshold to the border of life, and (3) building the semiotic models of living systems, i.e., the rise of biosemiotics.
\end{abstract}

The main issue of the 20th century has been the end of modernity. However, it has not yet been understood very well that this will also mean the end of the modern model of natural science. The modern age, as starting in the 17th century and being characterized particularly via the formation of experimental science together with the philosophy of Descartes and Bacon, would be replaced by anything that also replaces the experimental science, a strive for technological progress or innovation, and cartesianism. As John Deely $(2001 ; 2004)$ has stated, this can be semiotics. Several analyses have shown that much of what has been called post-modern is more like late modern, or ultra-modern (Deely 2003: 22), which means that we still see the extension of modern era. This particularly seems to be true for the modernist science, the current situation of which demonstrates large fluctuations and extremist approaches. It is not an entire end of 
science, however, it is an end of the science as we know its image from the modernity.

A study of meaning and semiosis cannot be provided via physics, even via physics of the 20th century. Because, in order to detect meaning, the measuring device has to be alive. And the question is whether a research that uses organisms instead of ruler could be called physics any more. It is more like biology, of course, but biology of a special kind - biosemiotics. As C. Emmeche has put it - it is an experiential biology, instead of experimental one. ${ }^{1}$

In this paper, I am not going to analyse the end of science as a modernist creation. However, since the period of modern science ending has its reflection in every field of knowledge, we cannot avoid the theme either. Still, this paper confines itself with biological knowledge only, attempting to understand the meaning of the semiotic turn in biology, or the meaning of the development of biosemiotics as an approach declaring a principal change in the fundamentals of biological theory - i.e., in biological understanding.

The age of modernity has been an age of revolutions, one after other (cf. Cohen 2001). In biology, the turn from preformism to epigenetics in 1830s, and the Modern Synthesis of 1930s, have been distinguished as the turns of major importance for biological understanding in last centuries (e.g., Mayr 1982). However, the turn that would consider biology not as a Naturwissenschaft, but rather a Bedeutungswissenschaft, would appear no less profound than any other in the history of biology since at least Carl Linnaeus.

Considering the turn in biology, or a remarkable shift in biological understanding, we find several quite different approaches to this, to the turn itself. At least three different aspects of the semiotic turn in biology should be distinguished. Namely, the semiotic turn in biology can be interpreted,

(1) as entering into a next phase or period in the historical development of biological understanding, e.g., from the modern to a type of postmodern;

(2) as a shift in the placement of the semiotic threshold - from the boundary of human culture, to the boundary of biological life; accordingly, life appears to be semiosis, biology being a part of semiotics;

1 Cf. Pesic 1999. 
(3) as a change of the theoretical basis for biology - the replacement of physical models by the ones of semiotic when interpreting the phenomena of life.

We are going to characterise the aspects of the turn briefly via a characteristic change in the deep models used in biological thinking, particularly the replacement of the archetypic model of tree by a model of web.

\section{Ladder, tree, web}

When interpreting the influences of biological ideas to other spheres of science (including humanities) in any period, or even to the biological discourse itself, the paradigmatic identification of the period and of the discourse would be necessary. For instance, the influence of biology to linguistics has been of several different kinds. On one hand, there exist the works of August Schleicher, who has applied the Darwinian model of diversification to language evolution (Dahlke 2001). And on the other hand, there exist works of Roman Jakobson of his Prague period, when using the ideas from the works of Karl Ernst von Baer and Lev Berg for the formation of his views on linguistic structuralism (Seriot 2001).

E. Mayr has noted that, despite some historians of science distinguish different periods, each with a single dominant paradigm (like T. Kuhn), or episteme (M. Foucault), or research tradition, "this interpretation does not fit the situation in biology" (Mayr 1982: 113). Indeed, there cannot exist any final and best periodization of the history of ideas, or the history of thought. Instead, there are several different, overlapping periodizations. The scientific debates can be characterized as relations between the different basic models or metaphors. This is because any model is situated in a context of other contemporary models, and the dialogue between these would create meaning and identity to any proposed one.

Among the metaphors, there exist some that characterise the very stable and basic models — archetypic models — used in the interpretation of knowledge in certain area. These are the ones we are going to describe and analyse here.

The basic metaphors form rows and opposites. This means, there are some that replace one another during the paradigm changes (like ladder/tree/web, or preformism/epigenetics). These are row meta- 
phors. And then, there are ones that appear as pairs, and as such seem to represent the eternal opposites (like holism/reductionism, or tychasm/anancasm) (cf. Berg 1969; Lyubischev 2000; Kull 2000a; 2000b).

Arthur Lovejoy (1964) has described in detail an early biological knowledge as organised on the basis of a deep model of ladder, scala naturae, and its replacement by a profound alternative during the Enlightenment. Accordingly, in the history of biology, three basic metaphors or models have been used that represent correspondingly three major types of paradigms:

(a) scala naturae, or ladder, or chain; this is a non-temporal model, a whole, in which the creatures differ in their level and complexity, however being complete (in plenitude) and non-evolutionary;

(b) tree, ever branching and growing arbor vitae; this model appeared in biology in concordance with the Enlightenment view that nature may be incomplete, and accordingly, there is an evolution towards perfection, a progress, ${ }^{2}$ this is the core of the Darwinian or Haeckelian view, where growth and divergence are the basic processes and competition being the progressive force; in classification, it corresponds to hierarchical systems;

(c) web, or network, tela; this seems to appear together with an ecological view that sees every creature to have a (symbiotic) role in the element cycles of ecosystem, or in an ideas of the biosphere and semiosphere that emphasise the interconnectedness, however it is rooted also in a Romanticist views to nature or early semiotic ideas; here, time is rather periodical, recognition and interpretation turn to be the important features of nodes, and the model of classification is non-hierarchic.

The change of the ladder-model by the tree-model in the 18th century included very much more than just a temporalizing the ladder. The basic idea, indeed, could be the (supposedly, Voltairean) idea that nature can be improved. ${ }^{3}$ If so, then it infers the situations of choice, i.e., the branching points of the path. The branching structure as such, the replacement a linear staircase by a hierarchic branchy form, as, e.g., used for classification purposes, may not itself still assume any

As Cassirer (1955: 5) has mentioned, "perhaps no other century is so completely permeated by the idea of intellectual progress as that of the Enlightenment".

According to Heelan (1994), a characteristic of modernity that the individual subject can authoritatively impose an order of things traces back to Luther. 
temporal dynamics. However, an application of the form of the tree to any set of facts, etc., implies an asymmetric representation, together with identification of a "stem" and divergences that provides good conditions for a temporal interpretation. Still, the first extensive representation of the system of organisms via the form of a branching model - the one of C. Linné - did not imply a temporal interpretation yet. However, it appeared soon, e.g., as the one by J. B. Lamarck.

The frequent usage of tree-like schemes as representations of the system of organisms does not go back much more than the first decades of the 19th century, according to M. Ruse (1996) who has made an attempt to trace the early usage of tree diagrams. ${ }^{4}$ There has also been found, for instance, a tree-diagram of types of ontogenies, drawn by K. E. v. Baer in 1827. Since E. Haeckel, the tree diagrams have been extensively used for representation of phylogenies.

The tree-model includes growth and sequential branching as builtin features. The exponential growth is just an implication from the tree structure. Also, tree model leads naturally to a problem of the insufficiency of space for all subsequent generations of branches, and thus to a concept of competition and survival. Accordingly, the Darwinian concept of evolution via struggle for existence and natural selection is an evident and natural implication from the tree-model (cf. Gould 2002: 146, 1334, 1342). Darwin's role was just to supply this model by examples that could illustrate its evolutionary interpretation.

The tree-model enforces an investigator to ask about the origins of the features under study, in order to identify the placement of the "stem". It also leaves one with thinking about the ever-going progress, and of endless fight for available resources.

The tree-model has spread, of course, to many areas. It has been applied almost in any science together with an evolutionary approach. Interesting parallels of its usage can be found, e.g., in linguistics (e.g., Sutrop 2000).

Most of the biology textbooks in the 20th century are so completely built on the basis of the tree-model that it might be very difficult to see any alternative to it. However, the model of web provides this.

4 The icon of arbor vitae is, of course, much older, e.g., as used in Christianity; however, it seems that earlier usage mainly refers to its features like bending, crossing, persistence, instead of hierarchy and growth. 
The web-model has been introduced mainly through two approaches. One is the idea of trophic network between the organisms in an ecosystem. The other is a representation of communication processes in a population, in a social community. Thus, these are the ecological and semiotic approaches that mainly begin to replace the tree-model by a web-model, a process that should be remarkable since 1960s.

The contemporary biology is using the web-metaphor widely. This includes cell biology ('metabolic web'), ecology ('trophic web', 'web of life', Capra 1996), evolutionary biology (e.g., 'the tangled web of life', Katz 1998). However, Darwin, for instance, did not use the term 'network' at all, and 'web' appears in the Origins of Species only twice.

The first appearance is in the chapter where Darwin speaks about the 'complex relations of all animals and plants throughout nature' (Darwin 1872: 59): "I am tempted to give one more instance showing how plants and animals, remote in the scale of nature, are bound together by a web of complex relations. I shall thereafter have occasion to show that the exotic Lobelia fulgens is never visited in my garden by insects, and consequently, from its peculiar structure, never sets a seed." And Darwin continues with examples about local plants, for which the pollinators exist and are often obligatory.

The second appearance of the word 'web' is in the chapter on classification: "We shall never, probably, disentangle the inextricable $w e b$ of the affinities between the members of any one class [...]" (Darwin 1872: 333).

It is interesting to mention that these are the only cases of the usage of the word 'web' in Darwin texts, in which this word appears in the functional or relational sense. All the other usage refers to the structural meaning, as for instance describing the spider's web.

As different from tree, web (as if) has no origin. Because web represents polyphyly, instead of a monophyly of tree. The nodes of web represent the points of meeting, not only divergence, thus recognition, co-existence and symbiosis, instead of competition. Web is a model for a communication network, not so much for a dominance of inheritance.

Thomas A. Sebeok, a biosemiotician, has emphasised the importance of web-metaphor: "Web conjures up the organic world of a spider, as well as, in their ineluctable correlations, its inorganic complement, the scaffolding of dry thread that the spider spins. Web 
suggests the reciprocal lives of both invertebrate and vertebrate creatures; it depicts the interplay between hub, spokes, and periphery; it kindles the dialectic of suspense and abatement; and many summon up still further cascades of contrasts or oppositions" (Sebeok 2000: 76). Thure von Uexküll (Uexküll et al. 1993: 9) has characterised an organism's body as a web of semioses.

When comparing the logics that are based either on dyadic or on triadic relations, J. Hoffmeyer (1996: 17-18) points out a simple feature - only triadic relations allow to build networks. He has used this as an argument for Peirce's approach that thus can be used in biology.

If the web-model can be identified as the one that is related to a semiotic approach, then the analysis provided by John Deely (2001) would be applicable also for biology. According to Deely, the Postmodern Age replaces the Modern via the semiotic understanding of sign, which has been given in the works of C. S. Peirce, and also, by Jakob von Uexküll.

The discussions on these three basic models and metaphors (scala, arbor, tela) have been superimposed in the history of biology by two alternative interpretations of the concept of natural system - either it to be as a real, actual, or as a potential, ideal. Accordingly, the research programs differ in a study of origins - one that requires a reconstruction of genealogy, and the other that is searching for a deduction from general laws.

There have been several other widespread deep models used in biology (e.g., map), however, of clearly lesser importance (Barsanti 1989; Gruber 1972).

As different from the ladder/tree/web periodization, which marks as focals the 1760 s and 1960 s, there can be seen a periodization on the basis of the models that treat dynamics - history/development/ evolution - with the turning points (or turning periods) of 1830s and 1930s. This marks the age of dominance of the developmental view in biology from the establishment of embryology around 1830, until the Modern Synthesis in 1930s. As E. Mayr has said, the idea of Darwinian evolution did not win before 1930s. In a larger perspective, there have been alternating periods of preformism and epigenetics in the history of biology. The Baer's work of 1827-1837 has been claimed to overcome a long period of preformism. His epigenetic emphasis has been replaced by a modern form of preformism genetic determinism, since 1930s. 


\section{Life as semiosis}

In 1986, in a conference on semiotics of cellular communication and immunological systems, in Italy, Umberto Eco was among the contributors. Attempting to ask about the features of sign processes in the cellular reactions that can distinguish between the alien and self, he still remained his hesitation. He finished his talk with these sentences (Eco 1988: 15): "As you probably understand, such a question concerns the dramatic problem of the boundaries between Spirit and Matter, Culture and Nature. Let me stop. I feel afraid."

U. Eco (1979) has formulated in his A Theory of Semiotics the concept of semiotic threshold. This is a boundary between the world of signs and the world of non-signs. At one side of this threshold there is the universe of meanings, at the other side - "stereochemistry": either the spatial correspondences between molecules, or the balances and imbalances of physical forces, but not anything "standing for something else".

Where is this semiotic threshold situated, and whether it exists at all? These questions have caused more than one debate.

According to Eco's quite clear statement in A Theory of Semiotics, "translation", as the term has been used by geneticists when they describe the relationship between nucleic acids and proteins, is only a concept transfer, a metaphor, without any concern to the nature of this process itself. In other words, the semiotic threshold, according to Eco, is situated on the boundary of culture.

Thomas Sebeok, a founder of zoosemiotics, has not agreed to Eco in this. Sebeok stated that there are sign processes in all living processes, and therefore, the semiotic threshold is placed at the boundary of life.

Signs are always connected to codes. Codes are the correspondences that cannot be inferred from the general physical laws. For instance, the fact that namely green light is permissive and not red neither yellow, does not follow anyhow from the universal laws about photons. The rules of lights are local, they became fixed in the history, they are bound to a culture.

Following Sebeok's approach, we notice that there are no universal laws in biology or in any other field that describe the phenomena of life and living. As different from the physical laws, biological rules do not hold universally, they include exceptions. This is because the biological rules represent codes, or because they are themselves codes. 
Thus, from the point of view of semiotic threshold, it is important to see the principal difference between the DNA-RNA and RNAprotein correspondences. The first is a code, the second is no. Guanosine fits cytidine due to stereochemical reasons; it is possible to predict it via calculations, there is no code. The relationship between a nucleotide triplet and an aminoacid in a protein, instead, is not due to stereochemistry, but due to sequences, the sequences that create the genetic code through the fixed order in the chains of transport-RNAs and aminotransferases. The gene sequences cannot be deduced from the universal laws of physics.

According to this approach, semiosis, the sign process, appears together with life. Which also means that there are many more codes - in addition to the genetic code - already in each cell (several of them have been illustrated by M. Barbieri 2003). Thus, the genetic code is not a metaphor - this is a true code. And there are no codes before the appearance of life.

When Eco discusses the concept of genetic code (Eco 1988: 7), he does not notice the difference described above - the one between transcription and translation in a cell. When he returns to this topic in his Kant and Platypus, asking how "lymphocytes have the capacity to distinguish infected from normal macrophages" (Eco 2000: 108), then he is going to allow speaking about a 'primary iconism' in the cellular level, however, again, he does not distinguish it from the 'primary iconism', e.g., of a trace of stone on sand.

Thus, one should distinguish between recognition as a biological, and interaction as a physical phenomenon. Recognition, as different from interaction, is based on a memory, i.e., it refers to something else via the relationship of the remembered. In this sense, we may say that enzymes are the simplest systems where recognition occurs. Enzymes may fit to their substrate not only due to their structure, but also due to the habit, due to the former interactions that have shaped it.

The life process is an endless self-interpretation. Namely in this code-dependent process, it is the same as endless semiosis.

The shift of the semiotic threshold from the Culture-Nature border to the one of Life-Non-life, took some time, and some research. At first, it was the zoosemiotic argument that Sebeok used, and only much later, probably influenced also by Uexküll, he arrived to the statement of coextensiveness of life and semiosis.

A difference between a dead and a living may appear no less great as the difference between being a (languageing) human or being an 
(other) animal. This would mean that we could speak about a semiotic threshold in both cases. And there may even be a third threshold - a semiotic threshold between the vegetative and the animal sign systems.

What exactly distinguishes between the different sign systems? This would be a topic for semiotic modelling.

\section{Semiotic modelling}

In late 1960s and early 1970s, during a peak of the 'general theory of systems' as initiated, e.g., by L. v. Bertalanffy, a search for a theoretical basis of biology led several biologists to an idea to apply the principles of semiotics in biology. Among them, it is important to mention at least four: C. H. Waddington (1972), who claimed that a paradigm of general biology should be taken from general linguistics; T. A. Sebeok $(1969 ; 1972)$, who developed semiotic models for analysis of animal communication; F. S. Rothshild (1962), who formulated first principles of biosemiotics; R. Jakobson, who interpreted the genetic phenomena in linguistic terms.

Since then, biosemiotics has slowly grown. It has found its forerunners, like Jakob von Uexküll (1928; 1982). It has established its first institutions, and became a university discipline, in 1990s (Kull 1999; 2001). There has been published a series of books (Sebeok, Umiker-Sebeok 1992; Hoffmeyer 1996; Deacon 1997; Emmeche et al., 2002; Markos 2002; Barbieri 2003; Weber 2003; etc.) and several special issues of journals devoted to biosemiotics - e.g., Semiotica vol. 120(3/4), 1998; 127(1/4), 1999; 134(1/4), 2001; Sign Systems Studies 30(1), 2002; Zeitschrift für Semiotik 18(1), 1996; Cybernetics and Human Knowing 10(1), 2003; European Journal for Semiotic Studies 9(2), 1997; etc. Annual meetings (Gatherings in Biosemiotics) as established by Copenhagen and Tartu biosemiotic groups, have turned into a regular event.

Despite of these rapid developments during the last decade or two, the semiotic theory of life is still in a period of formation. There are not many well-elaborated semiotic models to be applied in biological situations. However, there are some.

As U. Eco (1988: 14-15) has nicely put - "the properties of the model must be better known than the properties of the object" otherwise there will not be much use of a model. In physics, the 
models have almost always been more sophisticated than the observations. In a large part of biology it has never been so.

That the models of semiotics may look too simple for biology may seem so only in a superficial approach. The indirect information a semiotic model includes, itself being formulated briefly, can be huge.

Recently, a state-of-the-art of biosemiotic theory has been briefly reviewed by Emmeche et al. (2002). Thus, let me here list only some points that can be taken as tasks for the further work. Because, the development of semiotic models as applicable in biology is very much a task for the coming decades.

(1) Biological things — organisms, species — are systems that hold together due to communicative reasons. They are not natural kinds, likewise the linguistic things (e.g., a sentence, or a phoneme) are not natural kinds. They exist as communicative structures, as natural categories. The process that leads to their formation is generally analogous to the one of perceptual categorization.

(2) Biological species that appear due to biparental reproduction, are related to the width of the organisms' recognition window. The recognition concept of species is the one close to this biosemiotic model of species (Paterson 1993; Lambert, Spencer 1995).

(3) The discretization (a formation of discrete units) is a general feature of any communication system. Most probably, the formation of distinct tissues and tissue types in a multicellular organism is an example of the same general phenomenon. However, a general typology of biological units that are created by communication processes is yet to be done.

(4) The meaningful communication requires at least two codes and the asymmetry of partners. Diversification and stability as the general consequences of communication can serve as a basis for a biodiversity theory.

(5) Biological needs are the codes that relate innate instabilities to the behavioural forms or categories. Thus, biosemiotics provides an approach for a theoretical study of biological needs.

(6) A semiotic classification of the types of biological communication should be further specified. It should, particularly, include a theory of vegetative and animal (i.e., non-linguistic, or nonpropositional) sign systems - the sign systems that are functioning without, e.g., sentences, or narratives. Thus, despite there exist many good surveys about biological communication, the theory of the field is still in its youth. 
(7) Changes in the cellular interpretation of a genome may appear as a factor of evolution, on the basis of a mechanism close to the Baldwinian (Hoffmeyer, Kull 2003).

As Myrdene Anderson (2003: 298) has stated: "Biosemiotics transcends ordinary science through its attention to communication, a nondeterministic open process of self-realization". 5

\section{References}

Anderson, Myrdene 2003. Rothschild's ouroborus. Sign Systems Studies 31(1): 291-304.

Barbieri, Marcello 2003. The Organic Codes: An Introduction to Semantic Biology. Cambridge: Cambridge University Press.

Barsanti, G. 1989. La Scala, la Mappa, l'Albero. Florence: Sansoni Editore.

Berg, Leo S. 1969 [1926, 1922]. Nomogenesis or Evolution Determined by Law. Cambridge: The M.I.T. Press.

Blandino, Giovanni 1969. Theories on the Nature of Life. New York: Philosophical Library.

Capra, Fritjof 1996. The Web of Life. New York: Anchor Books, Doubleday.

Cassirer, Ernst 1955 [1932]. The Philosophy of the Enlightenment. Boston: Beacon Press.

Cohen, I. Bernard 2001 [1985]. Revolution in Science. Cambridge: The Belknap Press of Harvard University Press.

Dahlke, Agnes 2001. Das evolutionsbiologische Paradigma in der Linguistik. Aachen: Shaker Verlag.

Darwin, Charles 1872. The Origin of Species by Means of Natural Selection, or the Preservation of Favoured Races in the Struggle for Life. [6th ed.] London: John Murray.

Deacon, Terrence 1997. The Symbolic Species. London: Penguin.

Deely, John 2001. Four Ages of Understanding: The First Postmodern Survey of Philosophy from ancient Times to the Turn of the Twenty-first Century. Toronto: University of Toronto Press.

- 2003. The Impact on Philosophy of Semiotics. South Bend: St. Augustine's Press.

- 2004. Why Semiotics? New York: Legas.

Eco, Umberto 1979 [1976]. A Theory of Semiotics. Bloomington: Indiana University Press.

- 1988. On semiotics and immunology. In: Sercarz, Eli E.; Celada, Franco; Michison, N. Avrion; Tada, Tomio (eds.), The Semiotics of Cellular Communication in the Immune System. Berlin: Springer, 3-15.

- 2000 [1997]. Kant and the Platypus: Essays on Language and Cognition. San Diego: A Harvest Book, Harcourt.

5 Acknowledgements. To John Deely, Silvi Salupere, Myrdene Anderson. 
Emmeche, Claus; Kull, Kalevi; Stjernfelt, Frederik 2002. Reading Hoffmeyer, Rethinking Biology. Tartu: Tartu University Press.

Foucault, Michel 1994. The Order of Things. New York: Random House.

Gould, Stephen Jay 2002. The Structure of Evolutionary Theory. Cambridge: The Belknap Press of Harvard University Press.

Gruber, Howard E. 1972. Darwin's "Tree of Nature" and other images of wider scope. In: Wechsler, Judith (ed.), Aesthetics and Science. Cambridge: MIT Press, 121-140.

Heelan, Patrick A. 1994. Galileo, Luther, and the hermeneutics of natural science. In: Stapleton, Timothy J. (ed.), The Question of Hermeneutics: Essays in honor of Joseph J. Kockelmans. Boston, Dordrecht: Kluwer, 363-375.

Hoffmeyer, Jesper 1996. Signs of Meaning in the Universe. Bloomington: Indiana University Press.

Hoffmeyer, Jesper; Kull, Kalevi 2003. Baldwin and biosemiotics: What intelligence is for. In: Weber, Bruce H.; Depew, David J. (eds.), Evolution and Learning: The Baldwin Effect Reconsidered. Cambridge: The MIT Press, 253-272.

Jahn, Ilse (ed.) 1998. Geschichte der Biologie - Theorien, Methoden, Institutionen, Kurzbiographien. 3te Aufl. Jena: G. Fischer.

Katz, Laura A. 1998. Changing perspectives on the origin of eukaryotes. Trends in Ecology and Evolution 13: 493-497.

Kull, Kalevi 1999. Biosemiotics in the twentieth century: a view from biology. Semiotica 127(1/4), 385-414.

- 2000a. Copy versus translate, meme versus sign: Development of biological textuality. European Journal for Semiotic Studies 12(1): 101-120.

- 2000b. Trends in theoretical biology: the 20th century. Aquinas 43(2), 235-249.

— 2001. Jakob von Uexküll: An introduction. Semiotica 134(1/4): 1-59.

Lambert, David M.; Spencer, Hamish G. (eds.) 1995. Speciation and the Recognition Concept: Theory and Application. Baltimore: The John Hopkins University Press.

Lovejoy, Arthur O. 1964 [1936]. The Great Chain of Being: A Study of the History of an Idea (The William James Lectures delivered at Harvard University, 1933). Cambridge: Harvard University Press.

Lyubischev, A. A. 2000. Linii Demokrita $i$ Platona $v$ istorii kul'tury. SanktPeterburg: Aletejya.

Mandelker, Amy 1994. Semiotizing the sphere: Organicist theory in Lotman, Bakhtin, and Vernadsky. PMLA 109(3): 385-396.

Markos, Anton 2002. Readers of the Book of Life: Contextualizing Developmental Evolutionary Biology. Oxford: Oxford University Press.

Mayr, Ernst 1982. The Growth of Biological Thought: Diversity, Evolution, and Inheritance. Cambridge: The Belknap Press of Harvard University Press.

Merrell, Floyd 1991. Model, world, semiotic reality. In: Anderson, Merrell 1991: 246-283.

Nabielek, Rainer 1998. Biologische Kenntnisse und Überlieferungen im Mittelalter (4.-15. Jh.). In: Jahn 1998: 88-160.

Paterson, Hugh E. H. 1993. Evolution and the Recognition Concept of Species. Baltimore: The John Hopkins University Press. 
Peirce, Charles Sanders 1931-1935, 1958. Collected Papers of Charles Sanders Peirce. Vols. 1-6, Hartshorne, Charles; Weiss, Paul, eds. (1931-1935), vols. 7-8, Burks, Arthur, ed. (1958). Cambridge: Harvard University Press.

Pesic, Peter 1999. Wrestling with Proteus: Francis Bacon and the "torture" of nature. Isis 90(1): 81-94.

Prigogine, Ilya; Stengers, Isabelle 1984. Order out of Chaos: Man's New Dialogue with Nature. Toronto: Bantam Books.

Rothschild, Friedrich Salomon 1962. Laws of symbolic mediation in the dynamics of self and personality. Annals of New York Academy of Sciences 96: 774784.

Ruse, Michael 1996. Monad to Man: The Concept of Progress in Evolutionary Biology. Cambridge: Harvard University Press.

Sebeok, Thomas A. 1969. Semiotics and ethology. In: Sebeok, Thomas A.; Ramsay, Alexandra (eds.), Approaches to Animal Communication. The Hague: Mouton, 200-231.

- 1972. Perspectives in Zoosemiotics. The Hague: Mouton.

- 2000. Semiotics as bridge between humanities and sciences. In: Perron, Paul; Sbrocchi, Leonard G.; Colilli, Paul; Danesi, Marcel (eds.), Semiotics and Information Sciences. Ottawa: Legas Press, 76-100.

Sebeok, Thomas A.; Danesi, Marcel 2000. The Forms of Meaning: Modeling Systems Theory and Semiotic Analysis. Berlin: Mouton de Gruyter.

Sebeok, Thomas A.; Umiker-Sebeok, Jean (eds.) 1992. Biosemiotics: The Semiotic Web 1991. Berlin: Mouton de Gruyter.

Seriot, Patrik 2001. Struktura i tselostnost': Ob intellektual'nyh istokah strukturalizma v tsentral'noj $i$ vostochnoj Evrope 1920-30-e gg. Moskva: Yazyki Slavyanskoj Kul'tury.

Sutrop, Urmas 2000. From the 'Language Family Tree' to the 'Tangled Web of Languages'. In: Nurk, Anu; Palo, Triinu; Seilenthal, Tõnu (ed.), Congressus nonus internationales Fenno-Ugristarum 7.-13.8.2000 Tartu. Pars I: Orationes plenariae \& Orationes publicae. Tartu, 197-219.

Uexküll, Jakob von 1928. Theoretische Biologie. (2te gänzlich neu bearbeitete Auflage.). Berlin: Verlag von Julius Springer.

- 1982 [1940]. The theory of meaning. Semiotica 42(1), 25-82.

Uexküll, Thure von; Geigges, Werner; Herrmann, Jorg M. 1993. Endosemiosis. Semiotica 96: 5-51.

Waddington, Conrad Hal 1972. Epilogue. In: Waddington, C. H. (ed.), Towards a Theoretical Biology 4: Essays. Edinburgh: Edinburgh University Press, 283289.

Weber, Andreas 2003. Natur als Bedeutung: Versuch einer semiotischen Theorie des Lebendigen. Würzburg: Königshausen \& Neumann. 


\section{Лестница, дерево, сеть: \\ вехи понимания в биологии}

Главные биологические воззрения можно различить на основе глубинных моделей, которые одновременно организуют многие аспекты интерпретации и достаточно явно различаются в разные периоды. В статье рассматриваются три основные модели или метафоры: “холистская” модель природы как лестницы, характерная для эпохи, предшествующей XVIII веку, биологическая модель дерева начиная с конца XVIII века и постмодернистская модель сети. Тем самым замена научной модели Нового времени семиотической оказывается связанной со сменой модели дерева на модель сети и с созданием биосемиотики.

\section{Redel, puu, võrk: arusaamise ajastud bioloogias}

Peamisi bioloogilisi vaateviise saab eristada süvamudelite alusel, mis organiseerivad ühtaegu paljusid interpretatsiooniaspekte ning mis võrdlemisi selgesti erinevad eri ajastuil. Artiklis vaadeldakse kolme põhilist mudelit või metafoori - uusaja-eelset holistlikku looduse kui redeli mudelit, uusaegse bioloogia puu-mudelit, ning postmodernset võrgumudelit. Seega uusaegse teadusmudeli asendumine semiootilisega osutub seotuks puu-mudeli asendamisega võrgu-mudeli poolt ning biosemiootika kujunemisega. 